\title{
The Influence of the Approach of Realistic Mathematics and Motivation to Learn Mathematics Students On the Ability of Mathematical Modeling Students On Cubes and Beams in MTs Al-Majidiyah
}

\section{Herman Mawengkang}

Department of Mathematics, University Sumatera Utara, Medan, Indonesia,

Email: hmawengkang@yahoo.com

\begin{abstract}
This study aims to determine: (1) Whether the increased ability of the mathematical modeling of students who are taught with Realistic Mathematics learning is higher than students taught by expository (2) Whether there is interaction between learning motivation of student learning on the ability of the mathematical modeling students (3) How the process of resolving questions related to the ability of the mathematical modeling of the students on the Realistic Mathematics learning and expository. This research is a quasi experiment with research population is all students of class VIII MTs Al-Majidiyah Chart Stone. The sample in this research is class VIII A and VIII class B. The instrument used consisted of: (1) test the ability of mathematical modeling with the material of the cube and beam (2) pieces of the Question. The Data in this research were analyzed by using descriptive statistical analysis, analysis and parametric statistics. Statistical analysis of data was done with the t test analysis and anova 2 lines. The results showed that: (1) Increase the ability of the mathematical modeling of students who are taught with learning PMR higher than students taught by expository (2) there is No interaction between the learning that is used with the learning motivation of the students to the ability of the mathematical modeling student (3) the Process of the completion of the answers of students who are taught by using learning model PMR is better compared to the expository.
\end{abstract}

Keywords : Approach Of Realistic Mathematics, Expository, And Motivation To Learn 


\section{INTRODUCTION}

Learning-oriented mastery of the material is considered failed to produce learners who are active, creative, and innovative. Learners managed to "remember" the short-term, but failed to equip learners to solve problems in the life of the long-term. Therefore there needs to be a change in the approach to learning that is more meaningful so as to equip the learners in the face of life problems that faced now and in the future. In the Approach of Realistic Mathematics (PMR) students are required to be more active in developing the attitude of his knowledge of mathematics in accordance with the capabilities of each individual so that as a result gives the motivation and learning outcomes are more meaningful in the students. Thus the Approach of Realistic Mathematics (PMR) is a very useful approach in the learning of mathematics. Armanto (2002) further stated " with the Approach of Realistic Mathematics (PMR) in addition to students math learning also they got the sense that is meaningful about the use of mathematics in various fields. The approach of Realistic Mathematics (PMR) encourage students to learn more actively and more meaningful this means that students are required always think about an issue and they are looking for their own way to resolve, thus they will be more trained to always use the skills of his knowledge, so that knowledge and learning experiences they will be embedded for a considerable period of time. In the Approach of Realistic Mathematics (PMR) students are required to be more active in developing the attitude of his knowledge of mathematics in accordance with the capabilities of each individual so that as a result gives the motivation and learning outcomes are more meaningful in the students. Thus the Approach of Realistic Mathematics (PMR) is a very useful approach in the learning of mathematics. Armanto (2002) further stated " with the Approach of Realistic Mathematics (PMR) in addition to students math learning also they got the sense that is meaningful about the use of mathematics in various fields. The approach of Realistic Mathematics (PMR) encourage students to learn more actively and more meaningful this means that students are required always think about an issue and they are looking for their own way to resolve, thus they will be more trained to always use the skills of his knowledge, so that knowledge and learning experiences they will be embedded for a considerable period of time. Motivation is a state that is within a person that cause a person to do certain activities to achieve certain goals. Knowledge and understanding of learning motivation on students very bermamfaat for teachers to: awaken, increase, and maintain the spirit of the students to learn to succeed. The learning process will be successful when the students have a motivation in learning. Therefore, teachers need to foster students ' motivation. To obtain the results of the optimal learning teacher demanded to be creative arouse the students ' motivation. The accuracy of the selection approach in the process of learning mathematics and learning motivation students need to be considered so that educational goals can be achieved, it is necessary to examine how the influence of learning model and learning motivation with the title: the Influence of the Approach of Realistic Mathematics And Learning Motivation of the Students To the Ability of Mathematical Modeling Students On Cubes And Beams of Class Viii Mts Al-Majidiyah Bagan Batu

\section{RESEARCH METHODS}

\section{The Approach Of Realistic Mathematics}

The approach of Realistic Mathematics is a contextual learning. Contextual learning has been growing in developed countries with diverse names. In the Country of the Netherlands called Realistic Mathematics Education (RME). In America referred to by the 
term Contextual Teaching and Learning (CTL) (Kusnandar, 2007). In Indonesian by Soedjadi RME, defined as the Mathematics Education Realistik Indonesia (PMRI), and operationally is often referred to Approach Realistic Mathematics (PMR). The core of this approach is to link the subject matter to real life and motivate the learners to associate knowledge, which is learned with students ' everyday lives.

\section{Characteristics of PMR}

Learning mathematics based on the PMR need to show five characteristics, namely: (a) using contextual problem; (b) use the model; (c) use the contribution and production of the student; (d) interactive; (e) linkages (intertwinment). (Gravemeijer, 1994; Armanto, 2002). In the process of learning with PMR, the teacher should utilize the knowledge of students as a bridge to understand mathematical concepts through the provision of a contextual problem. Using A Contextual Problem.

In the PMR learning begins with the problem of contextual (real-world), so as to allow them to use previous experience directly. Then the student can apply mathematical concepts to the new field from the real world (applied mathematization). Therefore, to bridge the mathematical concepts with the child's experience of day-to-day need to be considered matematisasi experience day-to-day.

The learning process with PMR, the teacher should make use of the knowledge of the students as a means to understand mathematics concepts through the presentation of a contextual problem. According to Figuiredo (Pilgrim, 2005) the characteristics of the context in RME is (a) can be imagined, (b) associated with the world of students (c) not separate from the process of solving the problem, (d) begins with the knowledge of informal students and organized mathematically. Zulkardi (2008) explains about the role about the contextual learning in mathematics. According to him, learning math will be more meaningful and interesting for students if the teacher presents the problem-the problem of contextual and realistic, that is the problem-a problem that is already known, close to the real life day-to-day students. Problem konstekstual can be used as a starting point of learning math in helping students develop understanding of mathematical concepts learned and can also be used as a source of applications of mathematics. A contextual problem can be extracted from (1) the Situation of personal students; the situation with regard to students ' everyday lives, both at home with the family, with playmates, and so on. (2) the Situation of the school/academic; the situation with regard to academic life in the school and the activities related to the learning process. (3) the Situation of the community; the situation related to the life and activity of the community around students live. (4) a Situation scientific/mathematical; the situation related to the phenomenon of the substance for scientific or relating to mathematics itself.

Steps-steps PMR

According to Rahayu (2005) approaches to the study of PMRI has 5 (five) stages that need to be passed by the students, namely: problem solving, reasoning, Learning Outcomes, confidence, and representation (modeling).

- At the stage of completion of the problems, the students were invited to work on the questions by using the steps themselves. And that should be appreciated is that the use of this step is not applicable raw materials/same as used in the book or the teacher. Students can use the method that found itself, that even very different way/a method that is used by book or by the teacher.

- At the stage of reasoning, students are trained to reason in doing any questions to be done. That is, at this stage students should be able to account for the ways/methods used in the work on each question. 
- At the stage of Learning Outcomes, students are expected to produce Belajarkan the selected answer on his friends. The student is also entitled to refute (reject) the answers to a friend's who are considered not in accordance with his own opinion.

- At the stage of self-confidence, students are expected to be able to train your selfconfidence with the way the want to deliver the answers to questions he earned to his friends boldly forward to the front of the class. And if the answer chosen is different with answers friends, students want to present it with full responsibility and brave both orally and in writing.

- At the stage of representation, students gain the freedom to choose the form of the representation that she wants (concrete objects, pictures, or symbols of mathematics) to present or resolve the problems that he faced. He built his reasoning, his confidence through the form of the representation of his chosen.

\section{Research Design}

\section{RESULTS AND DISCUSSION}

The sample in this study are grouped experiment that the class X-1 taught by learning a model of Realistic Mathematics and class X-2 was also taught with the learning of a Mathematical model Realistic, so you can find out how influential with the learning Outcomes and motivation to learn mathematics students as well as make the group into homogeneous then some of the factors that make research into bias eliminated pursued.

Such factors are :

1. The initial knowledge of the students, carried out by providing a preliminary test to see if the student's knowledge of the same.

2. Lesson material, made of a material the same lesson.

3. Long delivery of second class the same.

4. The teacher who conveys the material of the lesson is the same person.

5. The time used in learning is not too much different between the two classes.

6. The final evaluation, done by giving the final test to determine the experimental Design is performed in the second grade.

Research Procedure

In this study, the steps taken are as follows :

1. Determine the sample in the form of classes of the population available by means of the random aim.

2. Composing learning media (props, WELDING, and others) that will be used during the teaching-learning process in the experimental group.

3. Develop research instruments in the form of a test of learning Outcomes and learning motivation to learn in the realm of cognitive to measure learning Outcomes and motivation to learn mtematika students.

4. Consult the instrument research with teachers of mathematics, mathematics lecturer, and lecturer.

5. Hold the validation of the research instrument is a test of learning Outcomes and motivation to learn mathematics

6. Carry out research that is imposed pemebelajaran model Realistic Mathematics to second class is based on syntax-the syntax of the model of Realistic Mathematics that has been stated previously.

7. Do the final test to find out how influential models of Realistic Mathematics learning Outcomes and motivation to learn mathematics students.

8. Analyze the research data and test the hypothesis. 
The Description Of The Results Of The Test The Ability Of Modeling The Experimental Class

In outline to the results of the tests the ability of mathematical modeling on the class of the experiment can be seen in the following table:

Table 1

\begin{tabular}{|c|c|c|c|c|c|}
\hline $\begin{array}{c}\text { Experimental } \\
\text { Class }\end{array}$ & $\begin{array}{c}\text { Maximum } \\
\text { Score }\end{array}$ & $X_{\text {maks }}$ & $X_{\text {min }}$ & $\bar{X}$ & SD \\
\hline Pretest & 14 & 8 & 0 & 2.23 & 2.22 \\
\hline Postest & 14 & 14 & 9 & 11.55 & 1.63 \\
\hline N-Gain & 14 & 1 & 0.583 & 0.80 & 0.13 \\
\hline
\end{tabular}

While so more clearly the difference of the pretest, posttest and $\mathrm{N}$-gain of the ability of mathematical modeling to experimental class can be seen in the bar chart below:

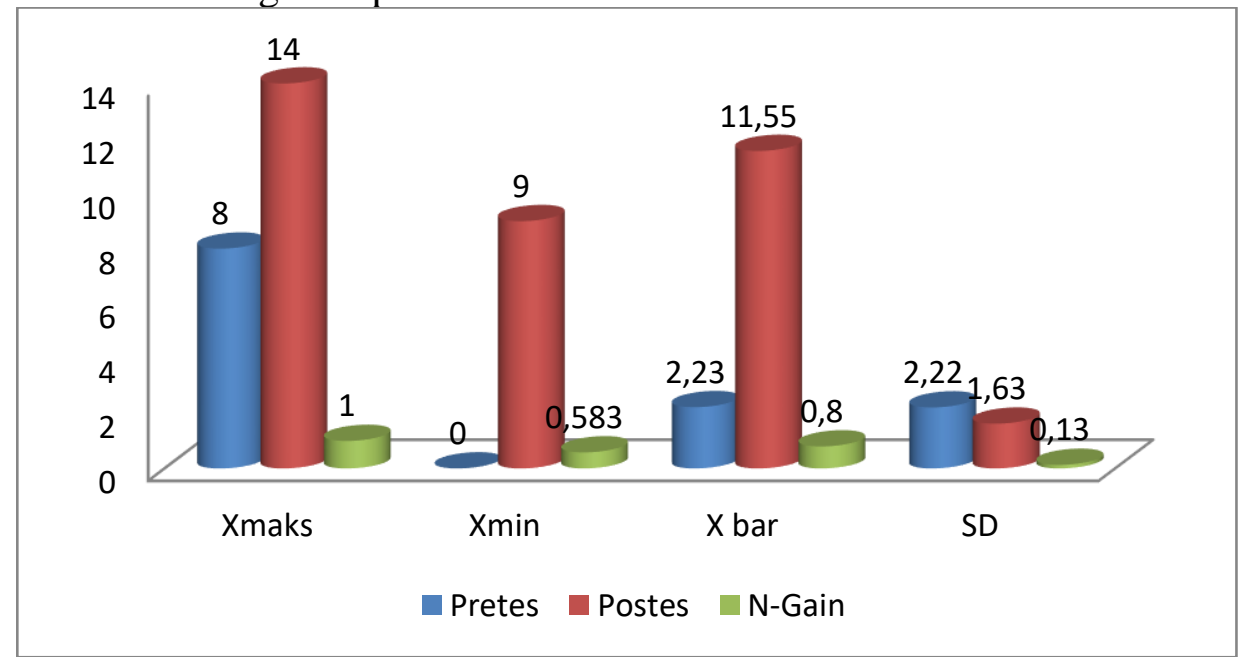

Figure 1. Diagram Batang Test The Ability Of Mathematical Modeling Of The Experimental Class

From Table 1 and figure 1 above it appears that from pretest obtained the highest score of 8 , the lowest Score of 0 , the average 2.23 and the standard deviation of 2,22. As for the post-test obtained the highest score of 14, the lowest score of 9, the average a 11.55 and a standard deviation of 1.63. In the experimental class is the average score of the test the ability of modeling the pretest and posttest when compared with the score distinguish is quite a lot different. So when seen from the average score is seen that the average score of posttest is higher than the average pretest score

\section{Description Of The Results Of A Test Of The Ability Of Modeling The Control Class}

Next to the control class, the outline of the results of the tests the ability of the mathematical model in this class can be seen in the following table: 
Table 1

\begin{tabular}{|c|c|c|c|c|c|}
\hline $\begin{array}{c}\text { Experimental } \\
\text { Class }\end{array}$ & $\begin{array}{c}\text { Maximum } \\
\text { Score }\end{array}$ & $X_{\text {maks }}$ & $X_{\text {min }}$ & $\bar{X}$ & SD \\
\hline Pretest & 14 & 5 & 0 & 2.75 & 1.85 \\
\hline Postest & 14 & 11 & 3 & 7.83 & 1.95 \\
\hline N-Gain & 14 & 0.750 & 0.182 & 0.45 & 0.15 \\
\hline
\end{tabular}

While so more clearly the difference of the pretest, posttest and N-gain of the ability of mathematical modeling for the control class is depicted in the bar chart below :

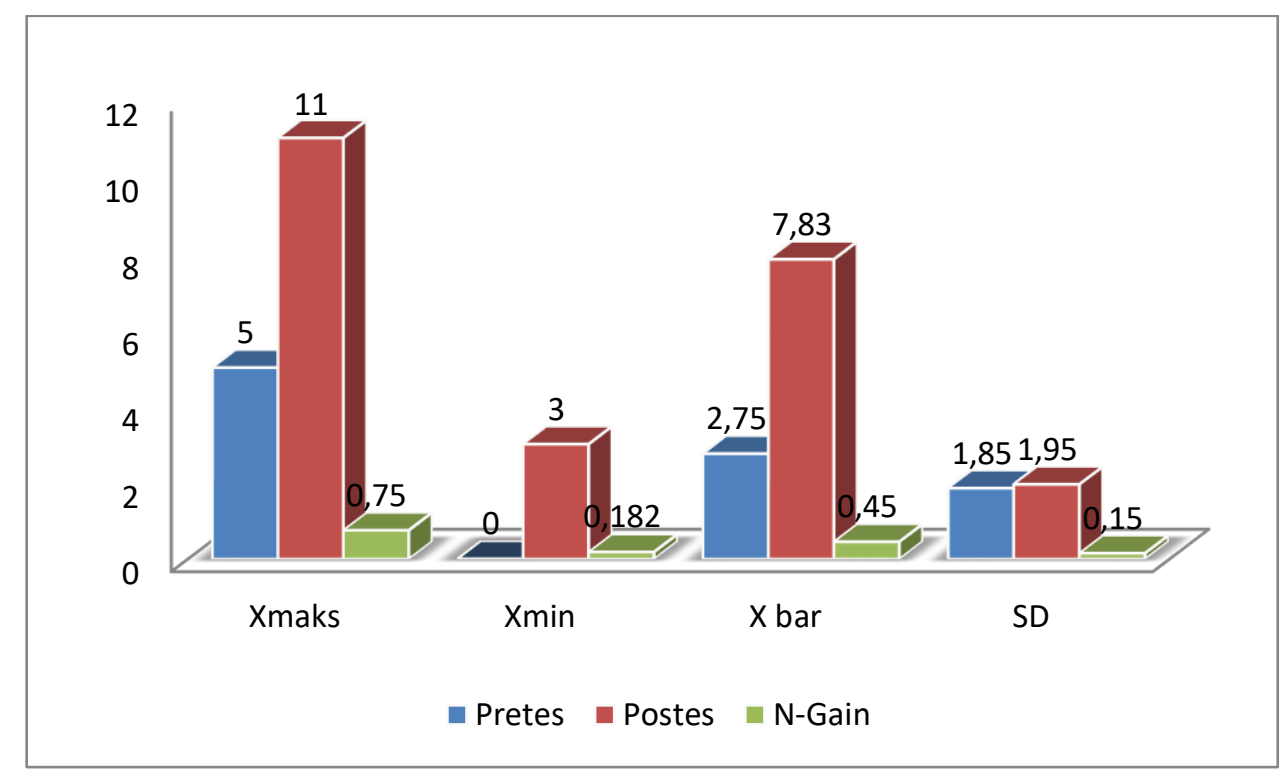

Figure 2. Diagram Batang Test The Ability Of Mathematical Modeling Of The Control

ClassFrom Table 2 and figure 2 above it appears that from pretest obtained the highest score of 5 , the lowest Score of 0 , the average of 2.75 and a standard deviation of 1.85 . While the highest score posttest 11 , the lowest score is 3 , the average 7,83 and standard deviation of 1.95. So it can be concluded that the average score of the ability of mathematical modeling are also increased in the control class, but of the average of the second class, the average in the experimental class is higher than in the control class.

\section{CONCLUSION}

Based on the results of the analysis of data from the field about the learning effect of PMR on the ability of mathematical modeling students of MTs, obtained some conclusions which is the answer to petanyaan-questions on the formulation of the problem, such as:

1. Increase the ability of understanding the concept of mathematics students taught through learning PMR higher than that taught by expository 
2. There is no interaction between learning approach PMR with the learning motivation of the students to the ability of the mathematical modeling students.

3. The process of the completion of the students ' answers through the study of PMR is better compared to the expository. It can be seen from the answer sheets of students in solving ability test the mathematical modeling students.

\section{REFERENCES}

Abdurahman, Muliono. (2003). Pendidikan Bagi Anak Berkesulitan Belajar. Jakarta: Depdikbub Rineka Cipta

A. Cholik \& Sugijono. (2003). Matematika untuk SLTP Kelas 2. Jakarta: Erlangga.

Arikunto, Suharsimi. (2003). Dasar-dasar Evaluasi Pendidikan. Jakarta: Bumi Aksara.

Armanto, Dian. (2001). Aspek Perubahan Pendidikan Dasar matematika melalui Pendidikan Matematika Realistik (PMR). Makalah disampaikan pada seminar nasional sehari Penerapan Pendidikan Matematika Realistik pada Sekolah Dasar dan Madrasah, tanggal 5 Nopember 2001, Medan. Tidak diterbitkan.

Dahar R. W. (1989). Teori-teori Belajar. Jakarta: Erlangga

Depdiknas. (2003). Model Pembelajaran Matematika Sekolah Dasar. Jakarta: Dikdasmen.

Haji, S. (2005). Pengaruh Pendekatan Matematika Realistik Terhadap Hasil belajar Matematika di Sekolah Dasar. Disertasi PPs UPi: Tidak ditebitkan.

Hasbullah. (2005). Dasar-dasar Ilmu Pendidikan. Jakarta:PT Raja Grafindo Perkasa.

Hidayat. (1996). Pendidikan dan Pembelajaran Yang Bagaimana Yang Cocok dan Berguna Untuk Siswa-siswi di Indonesia: Bandung: Khasanah Pengajaran IPA.

Jogianto, HM. (2007). Metodologi Penelitian Bisnis : Salah Kaprah dan PengalamanPengalaman. Yogjakarta: BPFE-Yogjakarta.

Junaidi, Syamsul dan Siswono, Eko. (2006). Matematika SMP untuk Kelas VIII. Surabaya:Gelora Aksara Pratama.

Mulyono (2008). Melalui PMRI Penghargaan Kepada Siswa Terbentuk . www.pmri+matematika.com didownload 02 Desember 2008. 